\title{
Management of High-Level Nuclear Wastes
}
A. M. Platt
J. L. McElroy

December 1978

Pacific Northwest I aboratory

Operated for the U.S. Department of Energy

by Battelle Memorial Institute 


\section{DISCLAIMER}

This report was prepared as an account of work sponsored by an agency of the United States Government. Neither the United States Government nor any agency Thereof, nor any of their employees, makes any warranty, express or implied, or assumes any legal liability or responsibility for the accuracy, completeness, or usefulness of any information, apparatus, product, or process disclosed, or represents that its use would not infringe privately owned rights. Reference herein to any specific commercial product, process, or service by trade name, trademark, manufacturer, or otherwise does not necessarily constitute or imply its endorsement, recommendation, or favoring by the United States Government or any agency thereof. The views and opinions of authors expressed herein do not necessarily state or reflect those of the United States Government or any agency thereof. 


\section{DISCLAIMER}

Portions of this document may be illegible in electronic image products. Images are produced from the best available original document. 
PNL-SA-7072/T1

MANAGEMENT OF HIGH-LEVEL

NUCLEAR WASTES

A. M. Platt

J. L. MCEl roy
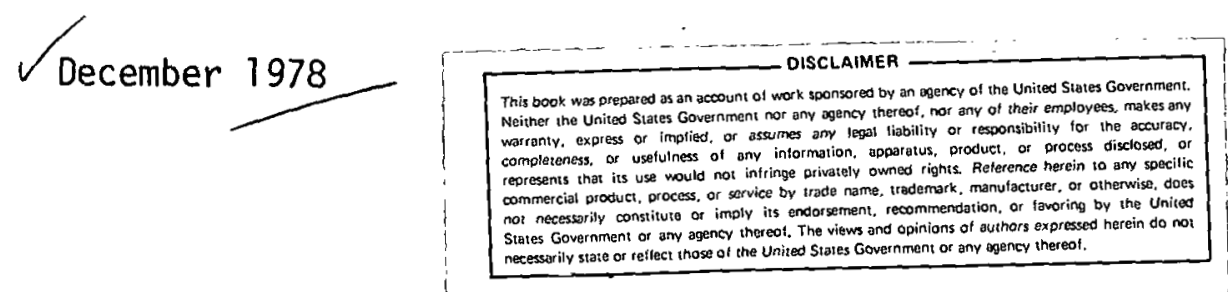

WORK SUPPORTED BY THE U.S. DEPARTMENT OF

ENERGY UNDER CONTRACT EY-76-C-06-1830

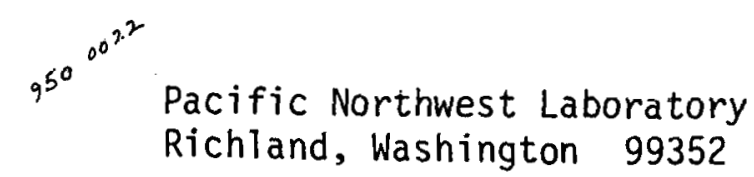




\section{THIS PAGE}

\section{WAS INTENTIONALLY LEFT BLANK}




\section{CONTENTS}

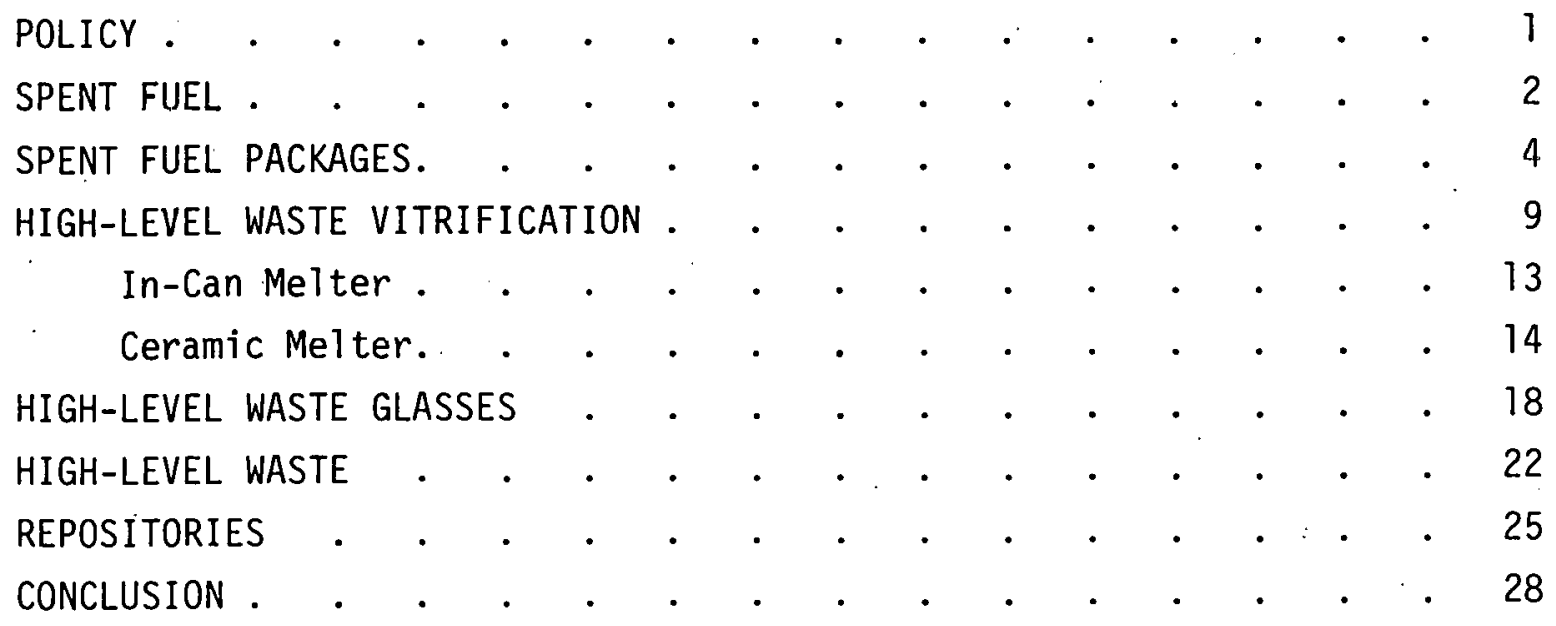




\section{FIGURES}

1 Primary Operations and Material Flows for Once-Through

Fuel Cycle . • . . . . • • • • • • • • 3

2 Primary Operations and Material Flows for Full Reutiliza-

tion of Plutonium ..$\quad \cdot \quad \cdot \quad \cdot \quad \cdot \quad \cdot \quad \cdot \quad \cdot \quad \cdot \quad \cdot 3$

3 Strategy 1 LWR Once-Through Heavy Element Flow Sheet per GWe-yr. . . . . . . . . . . . . . . 5

4 Strategy 2 LWR with Pu Recycle Light Water Reactor with Plutonium Recycle Heavy Element Flow Sheet per GWe-yr . . 5

5 High-Level Waste from Strategy 2 PWR . . . . . . . 7

6 Spent Fued trom Strategy 1 PWR . . . . . . . . . . . 7

7 KBS Spent Fuel Concept . . . . . . . . . . . 8

8 Schematic of Spray Calciner/In-Can Melter Process . . . . 10

9 Photograph of Spray/In-Can Melter in Engineering Development Laboratory. . . . . . . . . . . . . 11

10 Schematic of Spray Calcincr - Ceramic Melter System. . . . 15

11 Joule-Heated Continuous Melter in Engineering Development Laboratory . . . . . . . . . . . . . 16

12 Comparison of Corrosion Rates of Waste Glass and Other Durable Materials . . . . . . . . . . . .20

13 Temperature Effects on Glass Corrosion Rates . . . . . 20

14 Toxicity Index of Spent Fuel and High-Level Waste . . . . 23

15 KBS High-Level Waste Canister Concept . . . . . . . 24

16 Typical High-Level Waste Canister . . . . . . . . 25

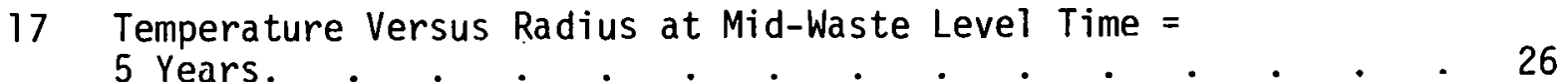

18 Reduction of Canister Wall Temperatures by (1) Aging or (2) Dilution of Waste . . . . . . . . . . . 27

19 Average Temperature Rise at Waste Disposal Level . . . $\quad 27$ 


\section{$\underline{\text { TABLES }}$}

1 LWR Nuclear Wastes, 10-Year Cooling, 1 GWe-Year . . . . . 6

2 Composition of a Typical High-Level Waste Glass Compared to a Durable Commercial Glass.

3 Energy Dissipated in Elastic Collisions by Various Nuclear Radiations, and Accumulations of Elastic-Collision-Energies in Radioactive Wastes. 


\section{MANAGEMENT OF HIGH-LEVEL NUCLEAR WASTES}

In this paper we briefly review significant developments in the management of high-level nuclear wastes that have occurred in the last 2 years. The principal thrust here is on the policy and technical developments in the United States, but some attention is paid to major developments in other countries which have impacted technical direction in the U.S.

\section{POLICY}

On April 7, 1977, President Carter announced major policy decisions regarding U.S. domestic nuclear policies and programs. The thrust of his message was that the benefits of nuclear power are very real and practical, but that a serious risk accompanies worldwide use of nuclear power--the risk that components of the nuclear power process will be turned to providing atomic weapons.

President Carter concluded that the consequences of proliferation and direct implications for peace and security--as well as strong scientific and economic evidence--require:

- a major change in U.S. domestic nuclear energy policies and programs; and

- a concerted effort among all nations to find better answers to the problems and risks accompanying the increased use of nuclear power.

In terms of U.S. LWR programs two immediate actions were taken. First, the commercial reprocessing and recycling of the plutonium produced in the U.S. nuclear power programs was indefinitely deferred. Second, the funding of U.S. nuclear research and development programs was redirected to accelerate our research into alternative nuclear fuel cycles which do not involve direct access to materials usable in nuclear weapons.

In autumn of 1977 a Task Force was formed under Dr. J. M. Deutch, Director of the Office of Energy Research, U.S. Department of Energy, to review all nuclear waste management programs of the Department as a first step toward 
formulation of an administrative policy.* Two of the findings of the committee are pertinent to this paper:

- A majority of independent technical experts have concluded that highlevel waste (HLW) can be safely disposed in geological media, but validation of the specific technical choices will be an important element of the process.

- Reprocessing is not required for the safe disposal of commercial spent fuel.

On March 15, 1978, President Carter also established an Interagency Nuclear Waste Management Task Furce, chaired by the Secretary of Energy, to formulate recommendations by 0ctober 1, 1978, for establishment of an Administration policy on long-term management of nuclear wastes and supporting programs to implement this policy.

The activities cited above have resulted in marked changes in the programs reported on previously by the authors. Specifically, our programs are now directed at the technical challenges posed by nuclear waste management in predisposal and disposal operations for LWR fuel cycles with spent fuel as a waste, the possible immobilization of U.S. military/dcfense waste for offsite disposal, and the nuclear waste management problems associated with proliferation-resistant fuel cycles.

\section{SPENT FUEL}

The International Nuclear Fuel Cycle Evaluation (INFCE) Working Group 7 has been developing material balances and waste arisings for LWR fuel cycles without and with plutonium recycle.

The primary operations and material flows for a once-through fuel cycle (INFCE WG/7 Strategy 1) are shown in Figure 1. Details of the LWR fuel cycle with full reutilization of plutonium as a fuel (INFCE WG/7 Strategy 2) are shown in Figure 2.

*DOE/ER-0004/D, Report of Task Force for Review of Nuclear Waste Management, February 1978. 


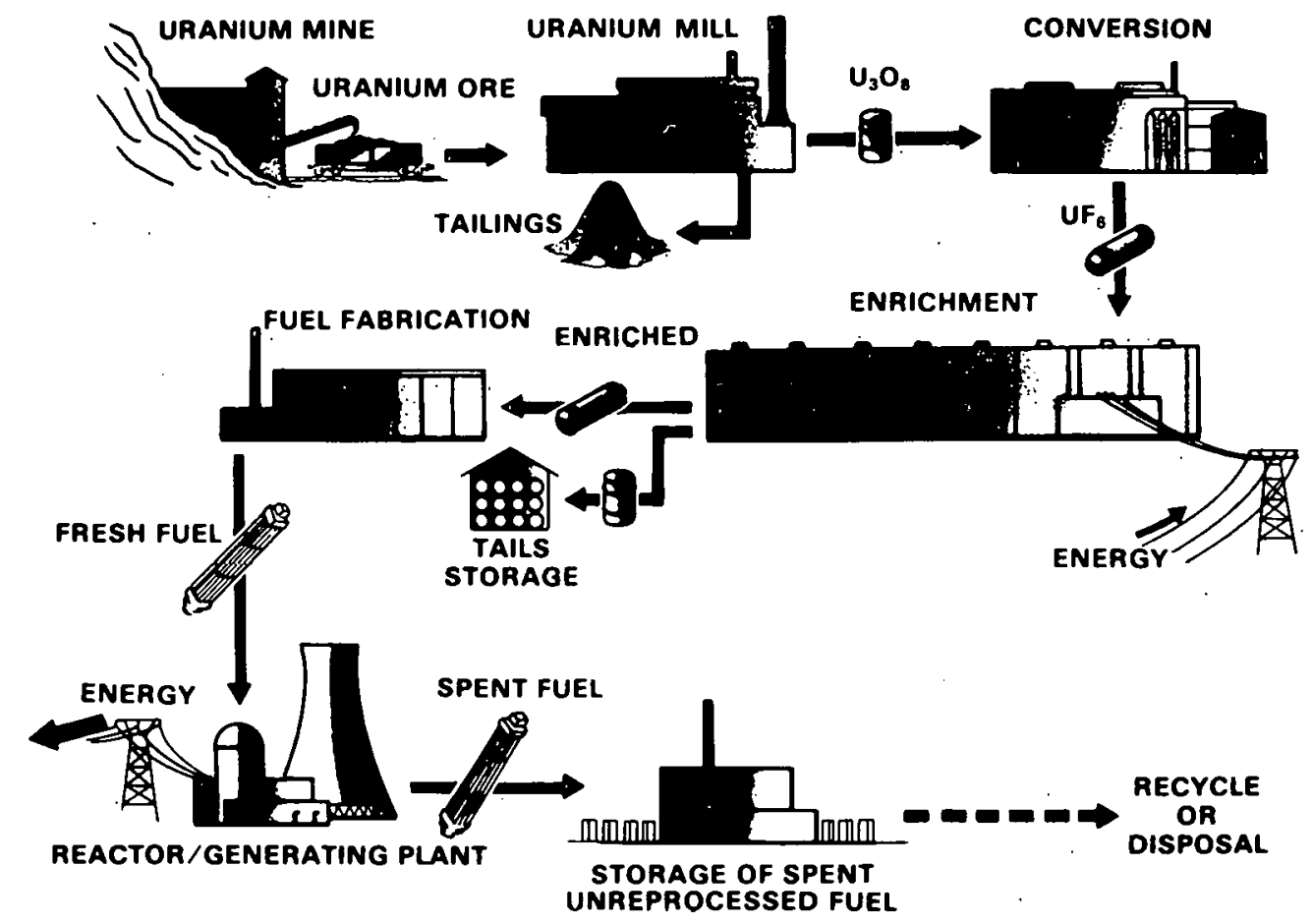

FIGURE 1. Primary Operations and Material Flows for Once-Through Fuel Cycle

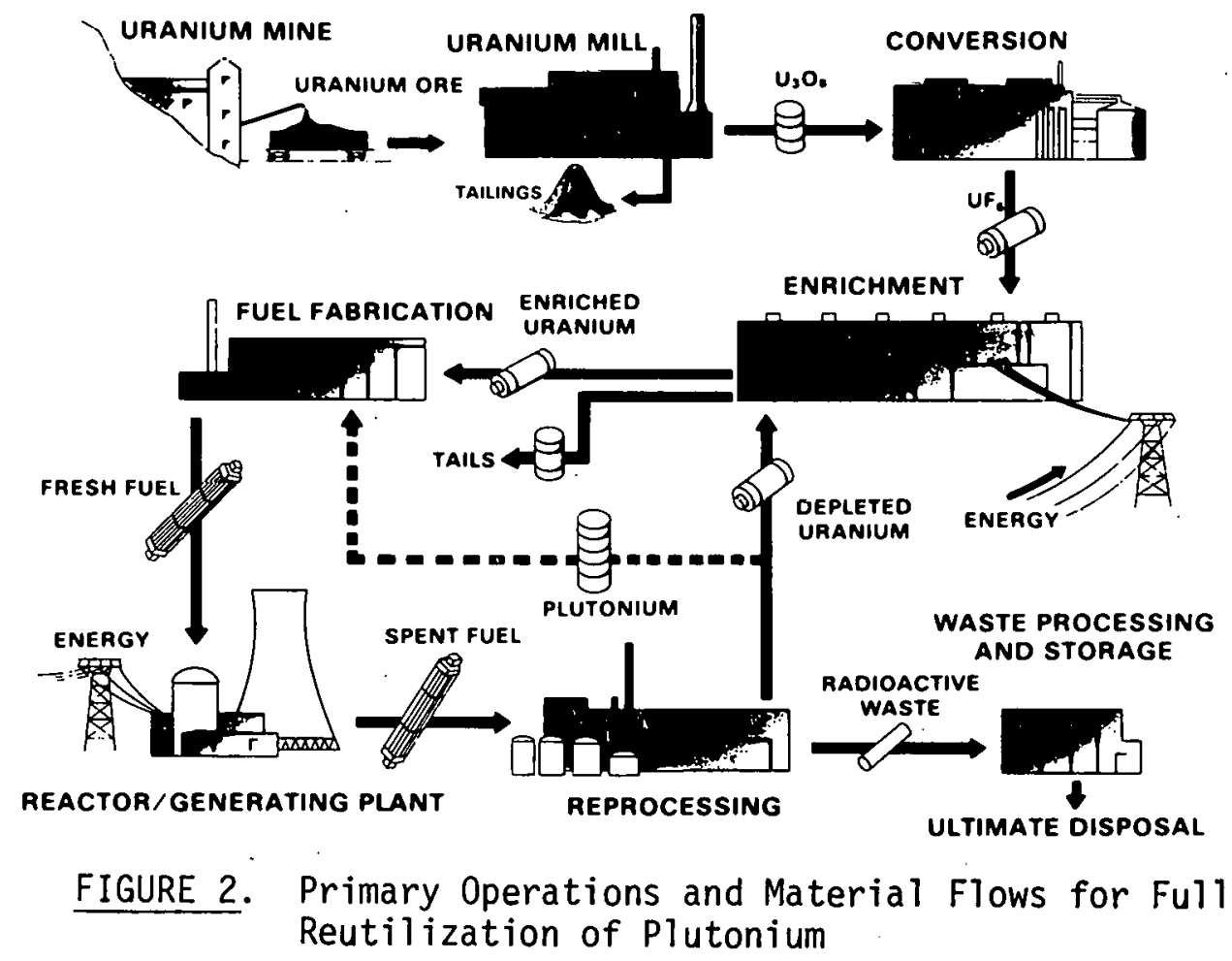


Detailed material balances for the two reactor strategies are shown in Figures 3 and 4 for LWR cycle generating a 1 GWe-year of electricity. A summary of the wastes requiring special treatment, e.g., disposal in a Federal underground repository, is shown in Table 1. Perhaps the key points are that the volume of wastes from Strategy 2 is about twice that from Strategy 1, but the aggregate fissile plutonium content in Strategy 2 is reduced about thirtyfold from Strategy 1 .

Regarding terminal storage/disposal considerations, it is also significant that the heat generation rates per unit of heavy metal fed to the reactors differ substantially only after long times (see Figures 5 and 6 ).

\section{SPENT FUEL PACKAGES}

Probably the most comprehensive study on packaging spent fuel has been conducted by the Swedish Project Kaernbraenslesaekerhet (KBS) set up in early 1977. At. the time this paper was written it appeared that their plan would call for 40 years of water pool storage of spent fuel in a granite cavern some $30 \mathrm{~m}$ underground.

After the 40-year storage, to let the heat dissipate, groups of 500 fuel rods ( 1.5 MTHM) would be loaded in a copper canister (Figure 7) $0.77 \mathrm{~m}$ in diameter with 20-cm walls. The canister would then be filled with lead and a copper cover welded onto the top. Each canister would weigh about 20 MT.

The canisters would be transferred to a final storage/disposal location in granite some $500 \mathrm{~m}$ underground. Here the canisters would bc placed in holes some $7.7 \mathrm{~m}$ deep and $1.5 \mathrm{~m}$ in diameter. The holes would be lined (sides, top and bottom) with $40 \mathrm{~cm}$ of isostatically compressed bentonite.

Early investigation by the KBS of three geologic study areas in granite showed potential for water flows of 0.1 to $0.2 \mathrm{l} / \mathrm{m}^{2} / \mathrm{yr}$. This, in part, was the logic for the sophisticated packaging system.

Several options are being investigated in the U.S. for encapsulating the spent fuel. The baseline option is placement of spent fuel in cantsters with only an inert gas fill. Other more advanced methods are under study as technical alternatives. These include a metal matrix fill, sand fill, other 


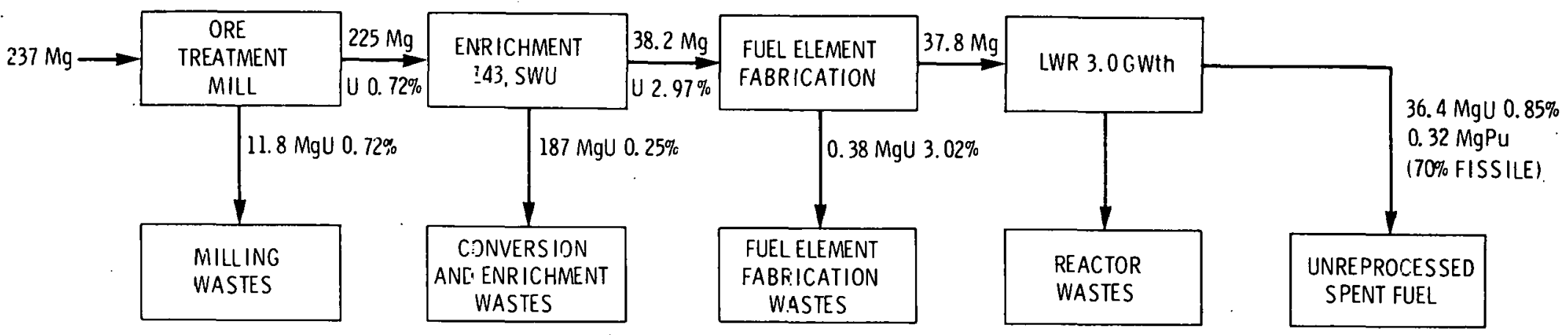

FIGURE 3. Strategy 1 LWR. Once-Through Heavy Element Flow Sheet per GWe-yr*

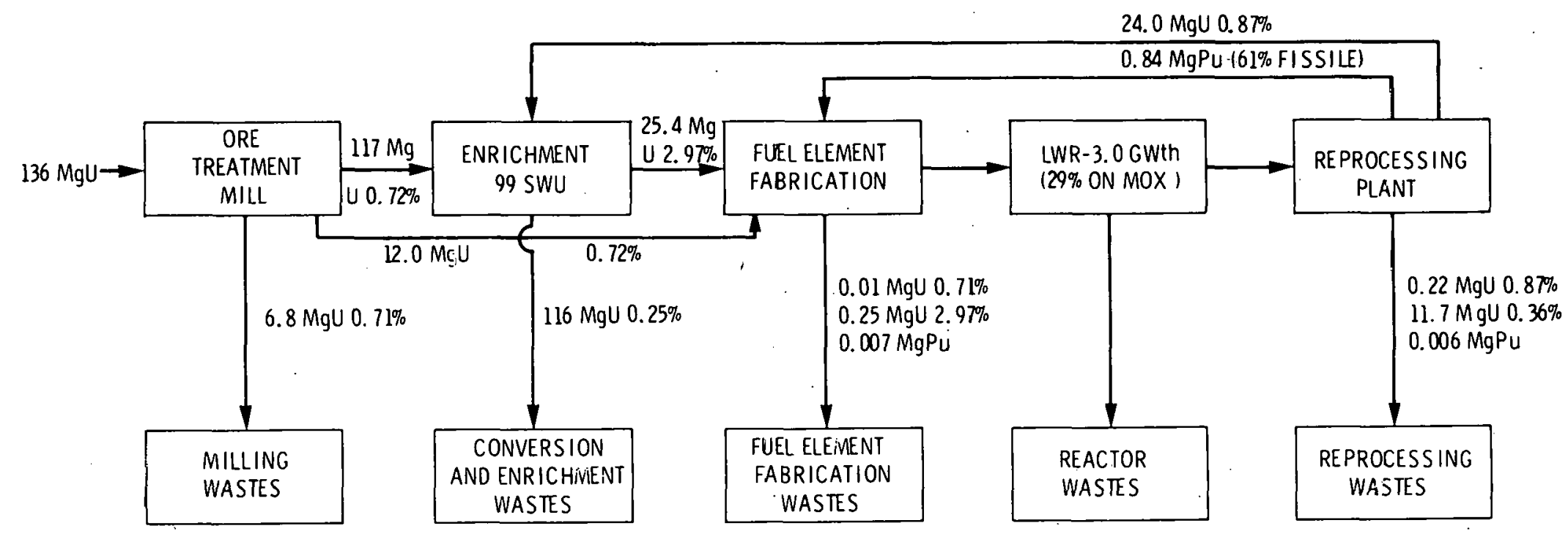

FIGURE 4. Strategy 2 LWR with Pu Recycle Light Water Reactor with Plutonium Recycle Heavy Element Flow Sheet per GWe-yr*

*Source: Uranium - Resources, Production and Demand, OECD/NEA-IAEA, Paris, December 1977. 
TABLE 1. LWR Nuclear Wastes, 10-Year Cooling, 1 GWe-Year UNREPROCESSED SPENT FUEL

Volume, $\mathrm{m}^{3}$

$\mathrm{U}, \mathrm{Mg} \quad 36.4$

$\mathrm{Pu}, \mathrm{Mg} \quad 0.31$

Radioactivity, MCi $\quad 13.0$

Conditioning Waste

$\begin{array}{ll}\text { Volume, } \mathrm{m}^{3} & 9 \\ \text { Radioactivity, } & k C i\end{array}$

REPROCESSING WASTES

Vitrified high-level waste

(10 years after discharge

from reactor)

Vnlume, $\mathrm{m}^{3}$

2.8

Contained $\mathrm{Pu}, \mathrm{kg}$

3.4

Radioactivity, MCi

10.4

Intermediate-level waste

Volume (in concrete), $\mathrm{m}^{3} \quad 52$

Contained $\mathrm{Pu}, \mathrm{kg} \quad 1.7$

Radioactivity, MCi 0.07

Hulls and spacers

Volume (compacted), $\mathrm{m}^{3} \quad 7.4$

Contained $\mathrm{Pu}, \mathrm{kg} \quad 0.24$

Radioactivity, MCi $\quad 0.03$

Mixed oxide fuel waste
Volume (in concrete), $\mathrm{m}^{3}$
18
Contained $\mathrm{Pu}, \mathrm{kg}$
0.65 


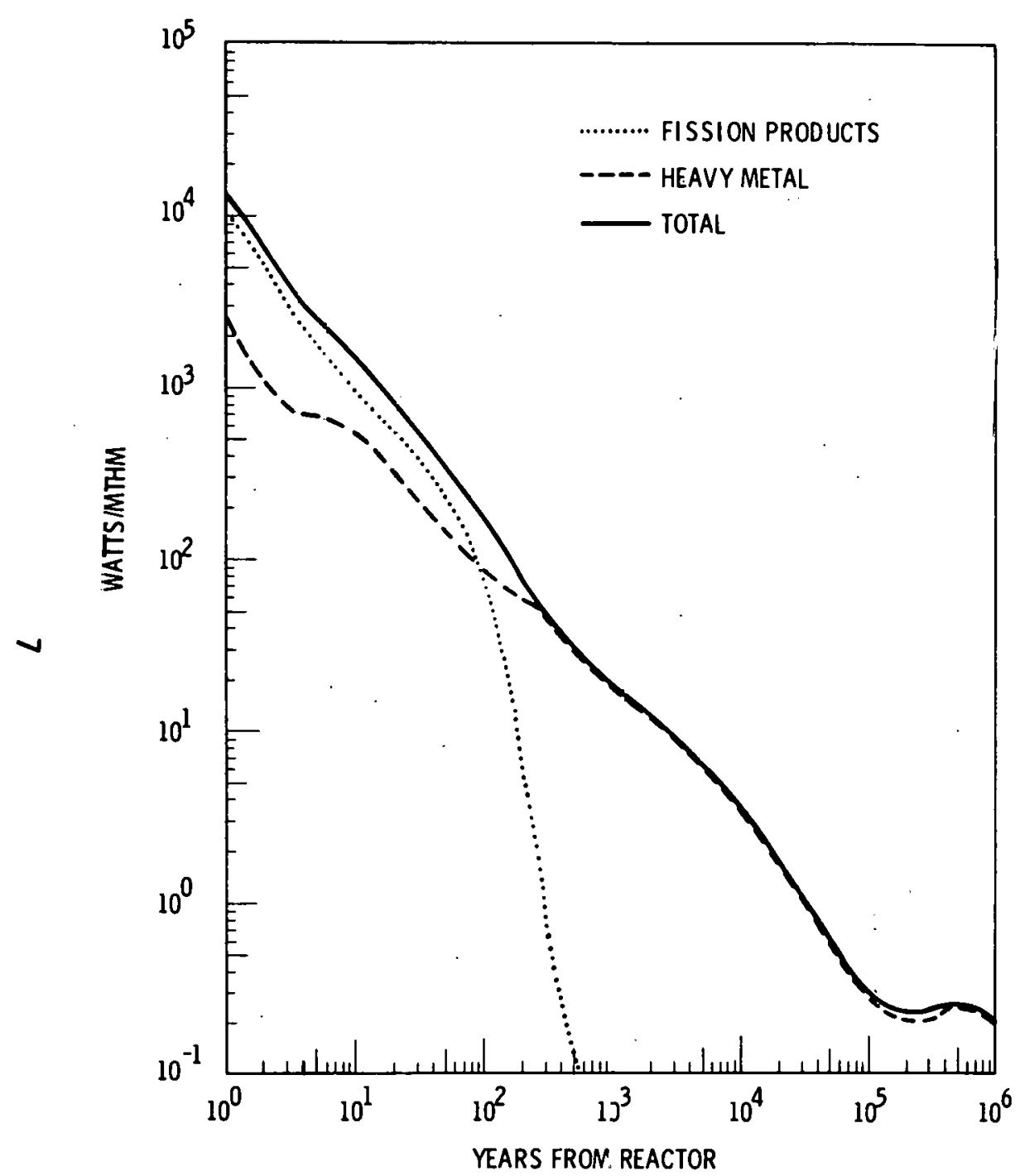

FIGURE 5. High-Level Waste from Strategy 2 P'NR

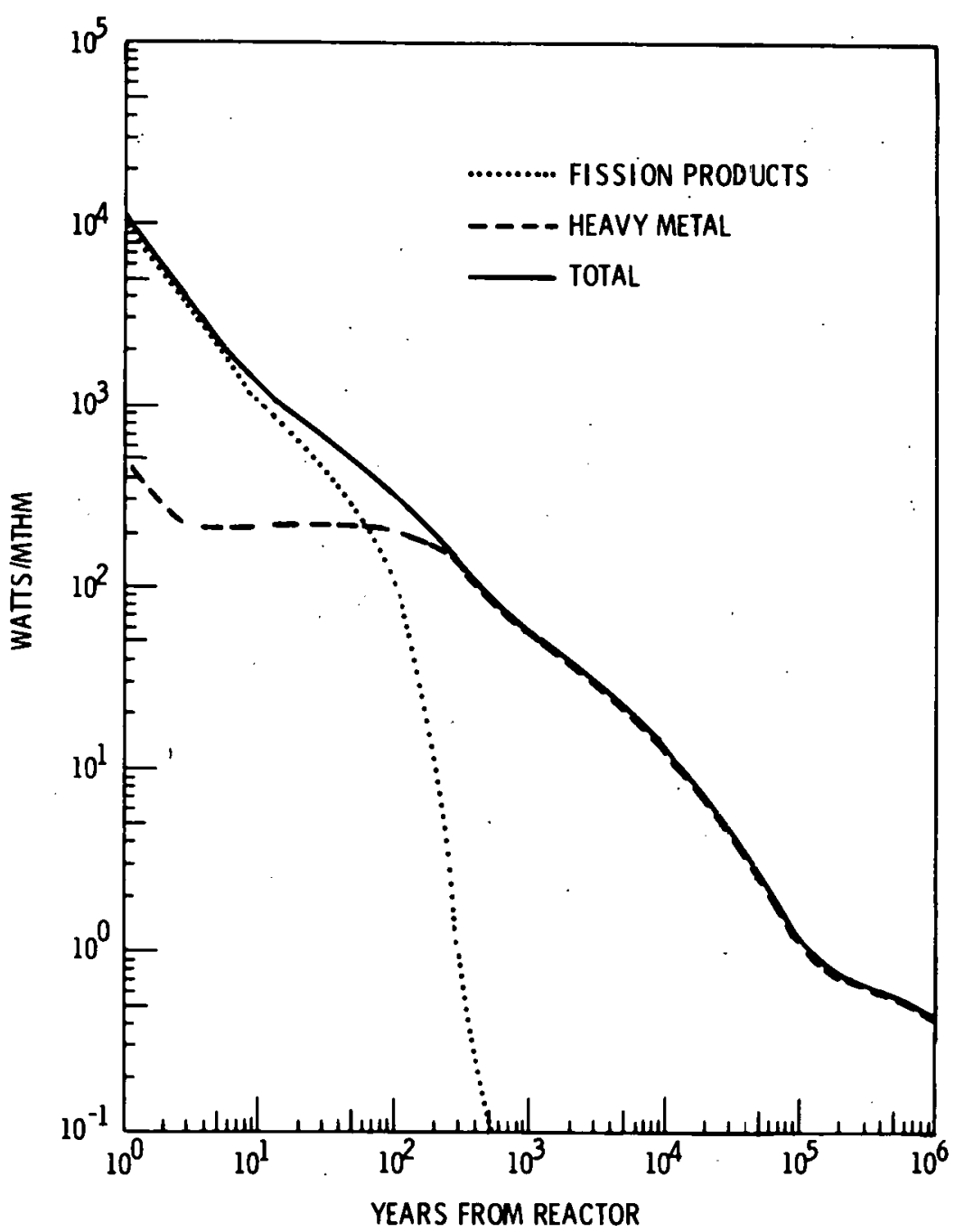

FIGURE 6. Spent Fuel from Strategy 1 PWR 


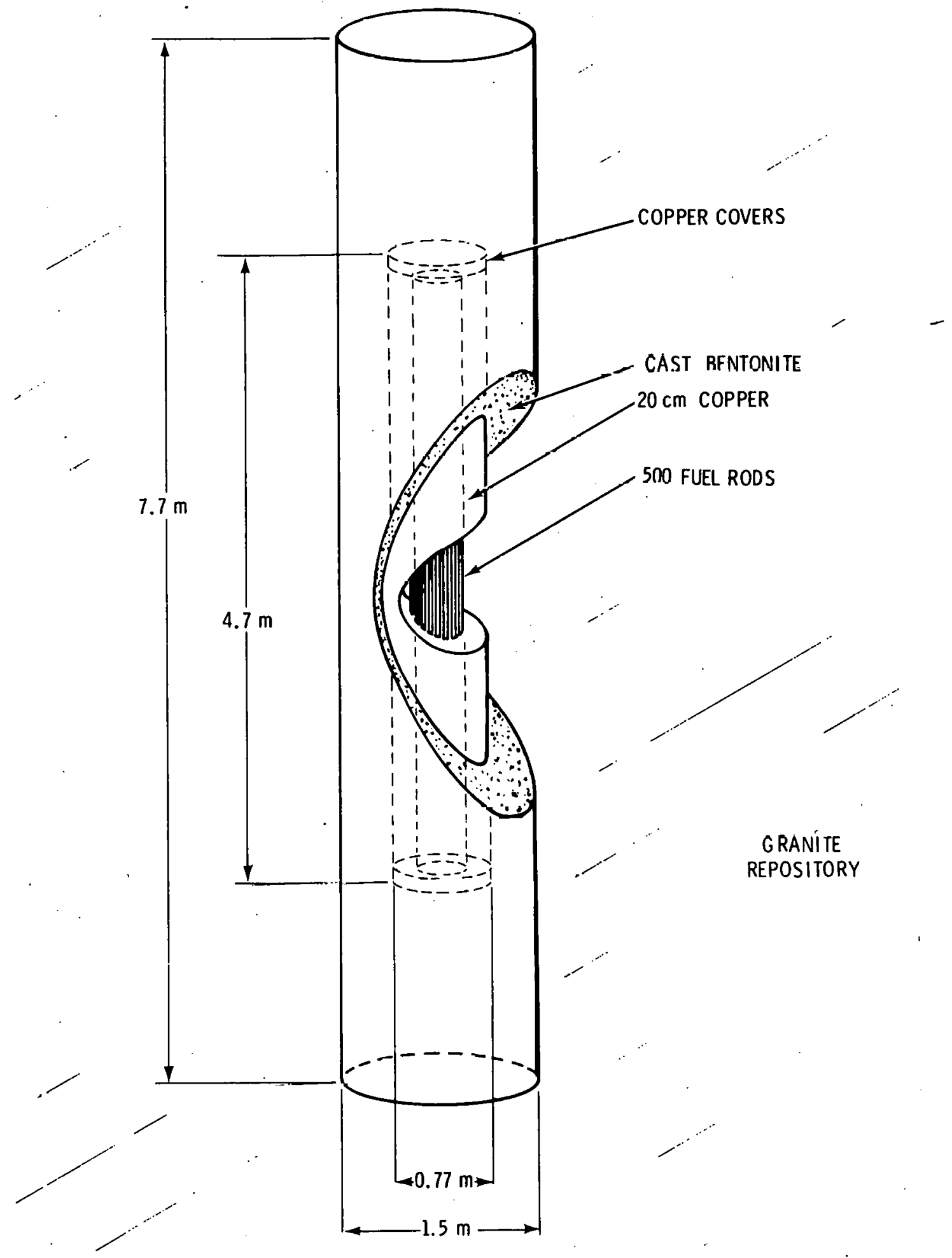

FIGURE 7. KBS Spent Fuel Concept 
glassy or ceramic materials, and multiple-barrier encapsulation of the spent fuel and canister at the time it is declared a waste for disposal. Presently, in the spent fuel program, Rockwell Hanford Operations (RHO) and Battelle, Pacific Northwest Laboratories (PNL) are studying the options for disposal. One of the first steps involves an evaluation of the sensitivity of the waste form to the performance of the geology for containment in a repository. In parallel with this work, sufficient technical information is being accumulated on the packaging and encapsulating options so that an assessment of the alternatives can be made by 1979-1980. That assessment is expected to provide a recommendation on whether any waste form other than the canistered spent fuel is desirable as a package for disposal of spent fuel as opposed to retrievable storage of spent fuel, where all the future options for reprocessing, continued storage, or disposal must be kept open for a future decision.

Experimental packaging and storage of spent fuel using facilities previously associated with the nuclear rocket program in Nevada is planned this fiscal year. Several packages will be prepared by Westinghouse-Nevada in the Engine Maintenance and Disassembly (EMAD) facility.

\section{HIGH-LEVEL WASTE VITRIFICATION}

As previously mentioned, U.S. activities in the area of high-level waste vitrification have been redirected towards defense/military wastes and those associated with proliferation-resistant fuel cycles.

At the First Pacific Basin Conference, J. L. McElroy described the Spray Calciner/In-Can Melter shown schematicdlly in Figure 8 and in the Engineering Development Laboratory in Figure 9.* This unit has been operated at rates over $300 \mathrm{l} / \mathrm{hr}$ ( $20 \mathrm{MTHM} /$ day) for periods of 400 operating hours. The unit has been exceptionally flexible regarding waste composition and has successfully treated fuels with a very high sodium content by adding silica to the feed stream.

\footnotetext{
*J. L. McElroy and W. A. Ross, "Alternative Solidified Forms for Nuclear Waste," Proceedings of the First Pacific Basin Conference, Honolulu, October 11-14, 1976.
} 


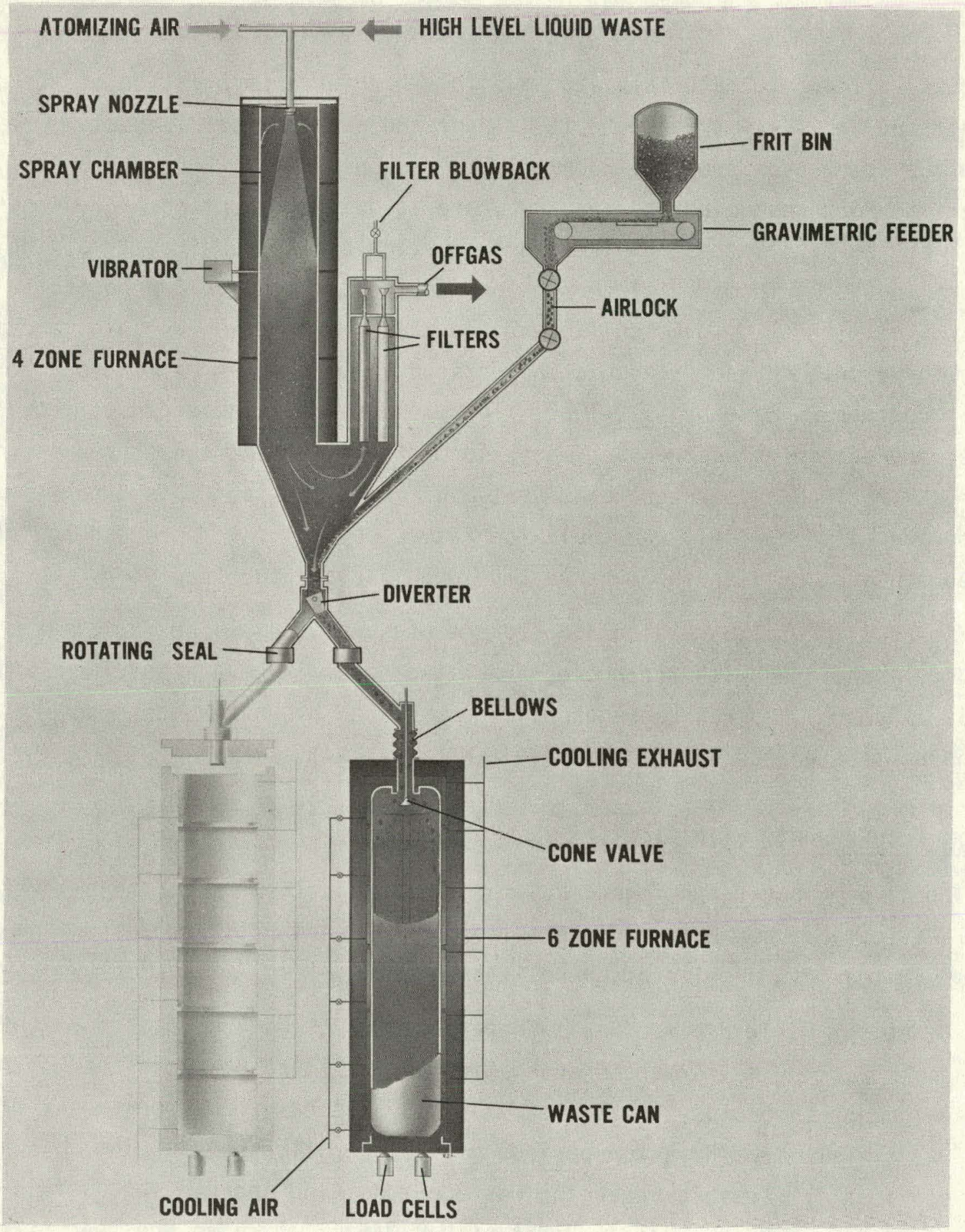

FIGURE 8. Schematic of Spray Calciner/In-Can Melter Process 


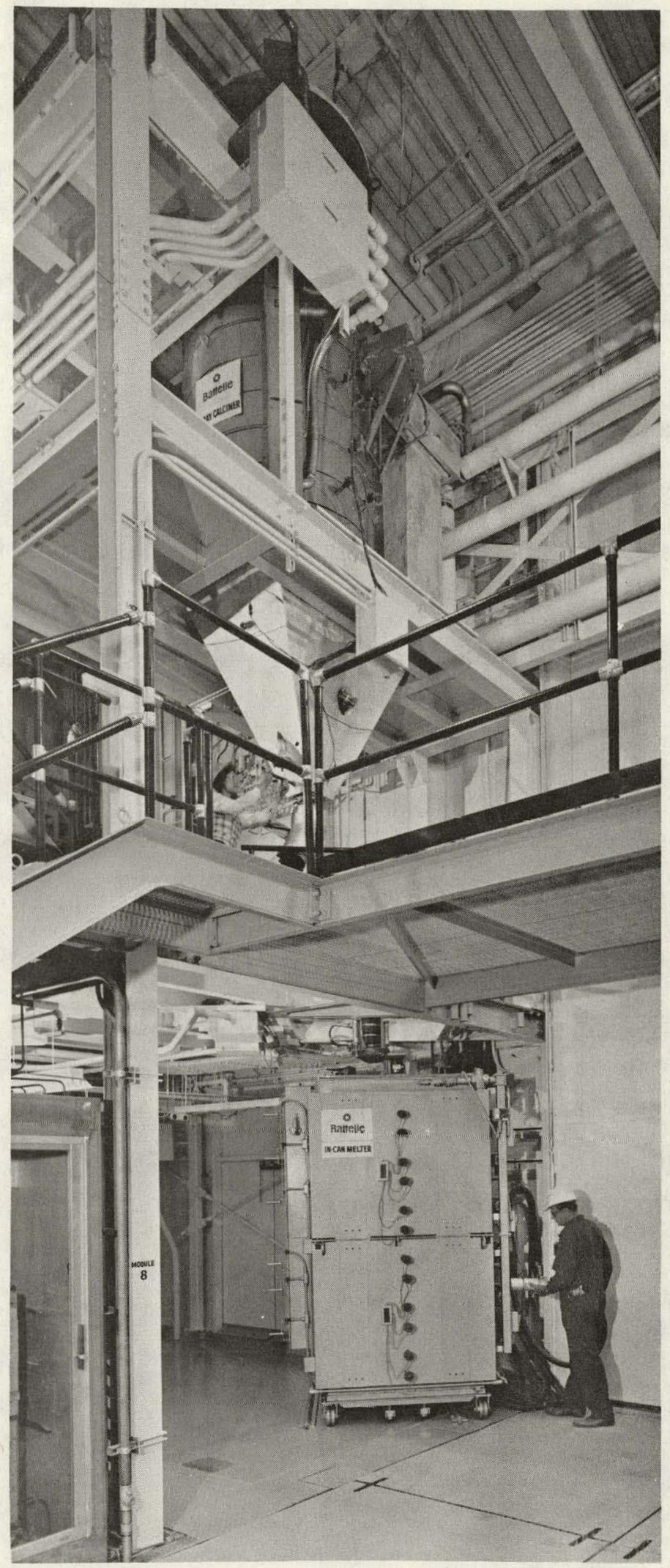

FIGURE 9. Photograph of Spray Calciner/In-Can Melter in Engineering Development Laboratory 
The principal advantages and disadvantages of the spray calciner are: Advantages

- Able to calcine all current LWR high- and intermediate-level wastes, defense wastes, and probable alternative fuel cycle wastes.

- Overall simplicity of the unit results in fast startup and shutdown and trouble-free operations, allowing simpler direct coupling to melter.

- Negligible inventory of radionuclides retained in the unit, allowing simpler direct coupling to melter.

- Demonstrated low release of radionuclides.

- Not significantly affected by process or waste composition variation during operation.

- Variable capacity (5 to $500 \mathrm{l} / \mathrm{hr}$ ) without major equipment change.

- Long life.

Disadvantages

- Capacity limited (current full-scale unit capacity is about $500 \mathrm{l} / \mathrm{hr}$ ).

- Requires use of vibrators to prevent scale buildup on chamber walls.

- Extreme high-sodium waste requires additives.

We feel that existing spray calciner technology is well developed and that it is a strong candidate for application to defense waste. Design and demonstration of a fully remote plant mockup designed to apprupriate codes, prior to construction of an actual high-level waste solidification plant, would be desirable. Operation of such a mockup would greatly reduce plant startup problems.

Current and future development is aimed at improving system reliability and safety, at investigating the effects of nonstandard operating conditions, and at demonstrating system compatibility with untested alternative fuel cycle (AFC) wastes. 


\section{In-Can Melter}

The in-can melter consists of a vertical, cylindrical, multizone furnace. Empty nuclear waste disposal canisters are placed in the furnace and heated to the processing temperature. A blend of calcined nuclear waste and glassforming frit is fed into the hot canister and melted. When the melt fills the canister, it is cooled and solidifies to a durable glass.

Major advantages and disadvantages of the in-can melter are:

\section{Advantages}

- Minimizes process steps.

- No melt transfer or valving required.

- Demonstrated low release of semivolatile radionuclides.

- Everything entering the melter, except some volatiles, is solidified in the the disposal can.

- Not adversely affected by reducing agents or by settling of dense phases.

- Long furnace life and no melter disposal.

- Able to process all current LWR high- and intermediate-level wastes, defense wastes, and probably AFC wastes.

- Simple design and control.

Disadvantages

- Melt temperature limited by canister material.

- Canister is subjected to high thermal and tensile stresses.

- Difficult to monitor product quality.

- Maximum demonstrated glass production rate is $100 \mathrm{~kg} / \mathrm{hr}$.

- Must routinely make and break a contaminated connection between the calciner and melter.

During its 10-year development history, the in-can melter has been demonstrated in lab-, pilot- and plant-scale systems. Over 40 engineering-scale canisters of nonradioactive glass have been produced. 
A fully remote pilot-scale system was successfully operated in a hot cell during the Waste Solidification Engineering Prototype Program (1966-1970) using actual high-level waste to produce 33 canisters of solidified radioactive waste. Two of these were radioactive waste glass produced by in-can melting.

The in-can melter itself is fairly well developed; however, three auxiliary components require further work. These are the calciner to melter connector, the canister weighing system, and the melt level detector.

Ceramic Melter

A relatively new development to replace the in-c.an melter is the jouleheated ccramic melter. Sludies on this concept for vitrification of nuclear wastes were initiated at the Pacific Northwest Laboratories of Battelle in late 1973, and work is now under way in both the FRG and USSR. The concept is illustrated in Figure 10, and an engineering-scale unit is shown in Figure 11.

The joule-heated ceramic-lined melter converts dry calcine and glassforming frit to a molten glass and delivers a controlled stream of glass to the receiving canister or to a glass shape-forming device. Process energy is supplied by passing an alternating current between immersed electrodes through the molten glass. Ceramic materials confine the molten glass.

In April 1978, a melter coupled to the plant-scale spray calciner and capable of producing glass at over $100 \mathrm{~kg} / \mathrm{hr}$ ( $10 \mathrm{MTHM} /$ day) was started up. Recent findings indicate:

- The tilt-to-pour concept in which melt discharges through an overflow has proven reliable.

- Inconel 690 electrodes continue to exhibit superior properties for highlevel waste glass use. After 2 years' operation, only minimal attack has been observed.

- Monofrax K-3 refractory, chosen for its outstanding corrosion resistance and its low electrical conductivity, has performed well. Even though subjected to repeated thermal shock when malfunctions occur during liquid feeding and even though smal1 cracks are seen in the refractory, significant spalling has not been observed. 


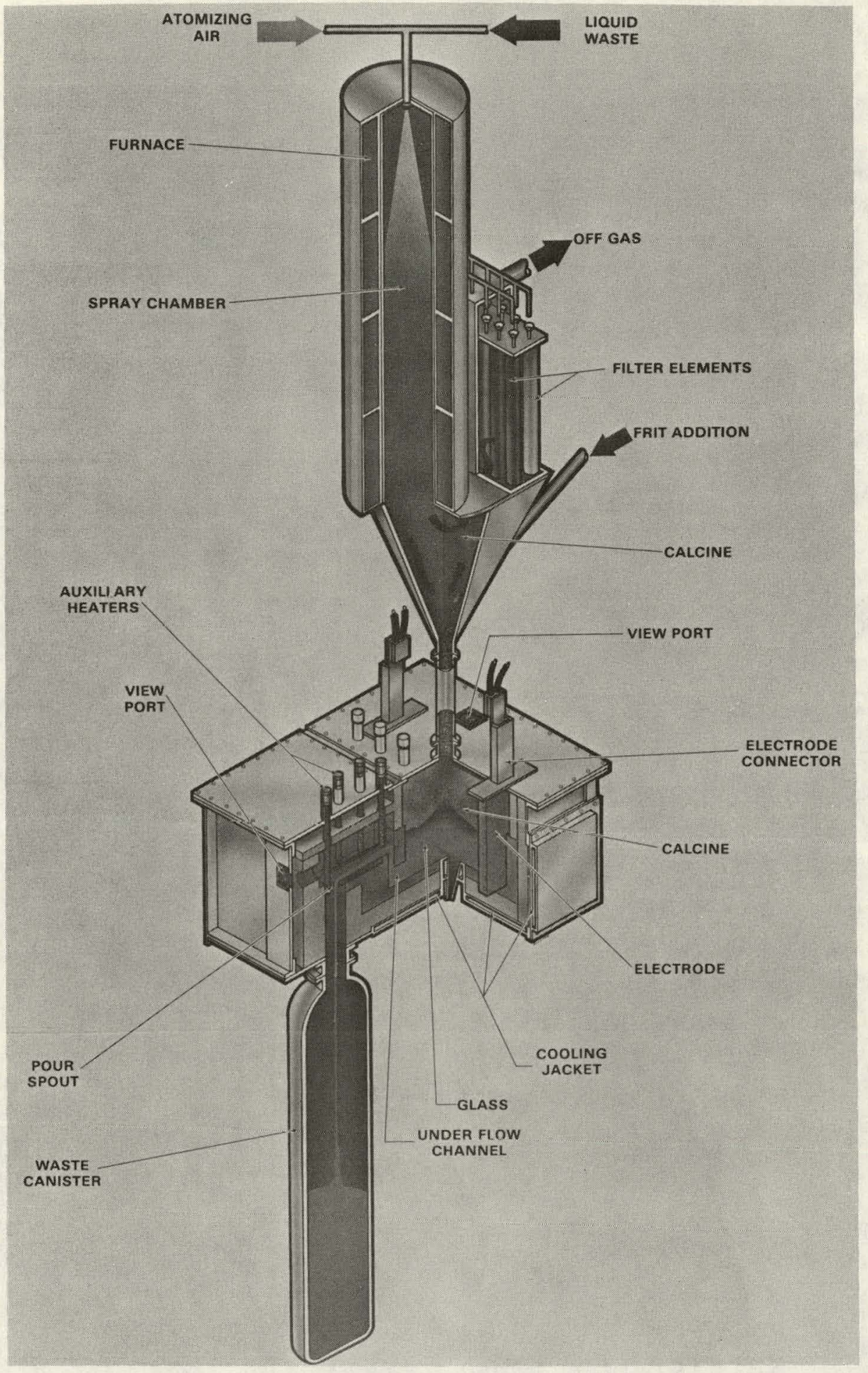

FIGURE 10. Schematic of Spray Calciner - Ceramic Melter System 


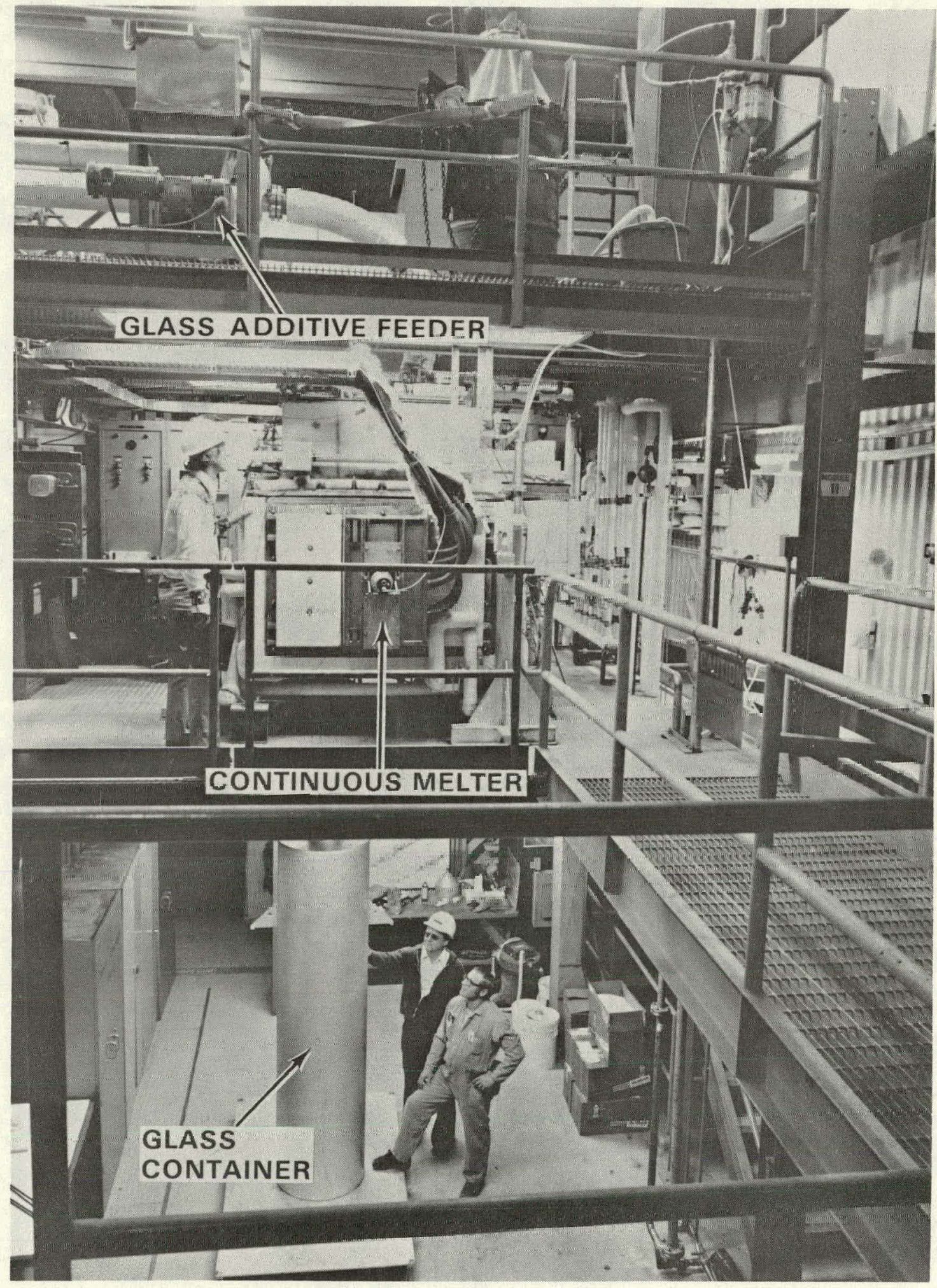

FIGURE 11. Joule-Heated Continuous Melter in Engineering Development Laboratory 
The spray calciner/ceramic melter combination has the following advantages and disadvantages:

Advantages

- Permits production of several waste forms - monoliths, marbles, etc.

- Canisters not subjected to temperatures over $600^{\circ} \mathrm{C}$.

- Capacity is practically unlimited.

- Produces high-quality glass.

- Long production life ( $(2 \mathrm{yr})$.

- Able to process all current LWR high- and intermediate-level wastes, defense wastes, and probably AFC wastes.

Disadvantages

- Startup and shutdown may take several days.

- Glass must be within a specified resistivity range.

- Molten metals and/or other high-density phases may settle to melter floor.

- Transfer and valving of molten glass required.

- Has not been tested under radioactive conditions.

The ceramic melter concept has been used by the glass industry for over 30 years. PNL has been developing the ceramic melter for use in solidifying high-level nuclear wastes for the past 4 years. Over $17,000 \mathrm{~kg}$ of nonradioactive glass have been produced, and melters have been at temperature for over 3 years without serious degradation to date.

The spray calciner/ceramic melter is the leading candidate for treatment of the defense waste at the U.S. Savannah River Plant. However, the ceramic melter has not been designed for, nor operated in, a remote hot cell. Consequently, a current major development thrust needed is design and demonstration of a remotely-operated melter. Other areas being further developed include: molten glass transfer and valving, high-density phase settling on the tank floor (sludge buildup and criticality), and melter control loops. 


\section{HIGH-LEVEL WASTE GLASSES}

The U.S., like many other nations, has selected borosilicate glasses as the principal contender for immobilization of high-level wastes--regardless of their origin.

A typical waste glass composition for HLW is shown. in Table 2 alongside that of a commercial "Pyrex" glass. Comparison of the compositions shows several major differences. Waste glasses with the need for high waste concentrations are low in silica. They also have additional alkali and alkaline earths to lower their processing temperatures. Waste glasses are typically melted at temperatures of 1050 to $1150^{\circ} \mathrm{C}$ whereas the commercial glasses are more typically melted at $\sim 1600^{\circ} \mathrm{C}$.

This borosilicate glass 76-68, shown in the table, evolved during the waste fixation program and has been extensively characterized. Tests have also been run on leachability and viscosity of samples of glass containing from 0 to $54 \mathrm{wt} \%$ waste.

The basic goal of the U.S. is to design a waste management system that will strictly limit the quantities of radioactivity that reach the biosphere. The properties of the waste form can contribute significantly to the success of such a system.

TABLE 2. Composition of a Typical High-Level Wastc Glass Compared to a Durable Commercial Glass

\begin{tabular}{|c|c|c|}
\hline & $\begin{array}{c}\text { Borosilicate } \\
\quad 76-68 \\
\end{array}$ & Pyrex \\
\hline $\mathrm{SiO}_{2}$ & 40 & 80.5 \\
\hline $\mathrm{TiO}_{2}$ & 3.0 & -- \\
\hline $\mathrm{Al}_{2} \mathrm{O}_{3}$ & -- & 2.2 \\
\hline $\mathrm{B}_{2} \mathrm{O}_{3}$ & 9,5 & 12.9 \\
\hline $\operatorname{Zn} 0$ & 5.0 & -- \\
\hline CuO & -- & -- \\
\hline $\mathrm{Na}_{2} \mathrm{O}+\mathrm{K}_{2} \mathrm{O}$ & 7.5 & 4.2 \\
\hline $\mathrm{MgO}+\mathrm{CaO}+\mathrm{Sr} 0+\mathrm{Ba} 0$ & 2.0 & -- \\
\hline Waste & $33.0 \%(P W-8 a)$ & -- \\
\hline
\end{tabular}


Thus we are concerned about the effects of time, temperature and radiation on the mechanical strength and leachability of the glasses. Taking these in turn, Figure 12 indicates the relative chemical durability or leach rate of typical materials compared with waste glass in $99^{\circ} \mathrm{C}$ distilled water. As would be expected; deionized water is probably more corrosive than any media generally available in natural surroundings. Secondly, the fundamental.s advocated by Arrhenius still hold. The rate of reaction increases with absolute temperature.

Both these effects are shown in Figure 13. Deionized water has a corrosion rate about an order of magnitude greater than a typical brine solution. The corrosion rate increases 300-fold with 10-fold increase in temperature from 25 to $250^{\circ} \mathrm{C}$. However, the corrosion rates are so high at $250^{\circ} \mathrm{C}$ that the waste form is no longer a significant barrier.

Maintaining the glass at high temperature can cause devitrification. Such devitrification is not desirable, but is not catastrophic. Soxhlet leach rates increase nearly an order of magnitude for samples devitrified at $700^{\circ} \mathrm{C}$, the temperature of maximum devitrification for $\mathrm{Zn}-\mathrm{B}-\mathrm{Si}$ waste glass. Samples for this test were held at the respective temperatures for two months before leach testing. The change in leach rate due to thermal effects is the major change identified in waste glasses.

Table 3 shows some displacement rate calculations from the various radiation damage sources present in radioactive wastes. Note that even at. 12 years, alpha decay produces $295 \%$ of all displacements, a fraction which greatly increases at long times since the major beta emitters have 230 year half-lives $\left({ }^{137} \mathrm{Cs},{ }^{90} \mathrm{Sr}\right)$.

The radiation effects work undertaken at PNL relies heavily on doping methods using the alpha emitter ${ }^{244} \mathrm{Cm}\left(t_{1 / 2}=18 \mathrm{yr}\right)$. Because the alpha flux in actual storage decreases significantly at long times, experiments using this technique can simulate $10^{5}$ years storage in a few years of laboratory time. A program using ion bombardment techniques has been initiated to extend understanding to beyond $10^{6}$ years. In the curium doping work, stored energy, volumetric changes, helium diffusion, and leaching behavior have been investigated. 


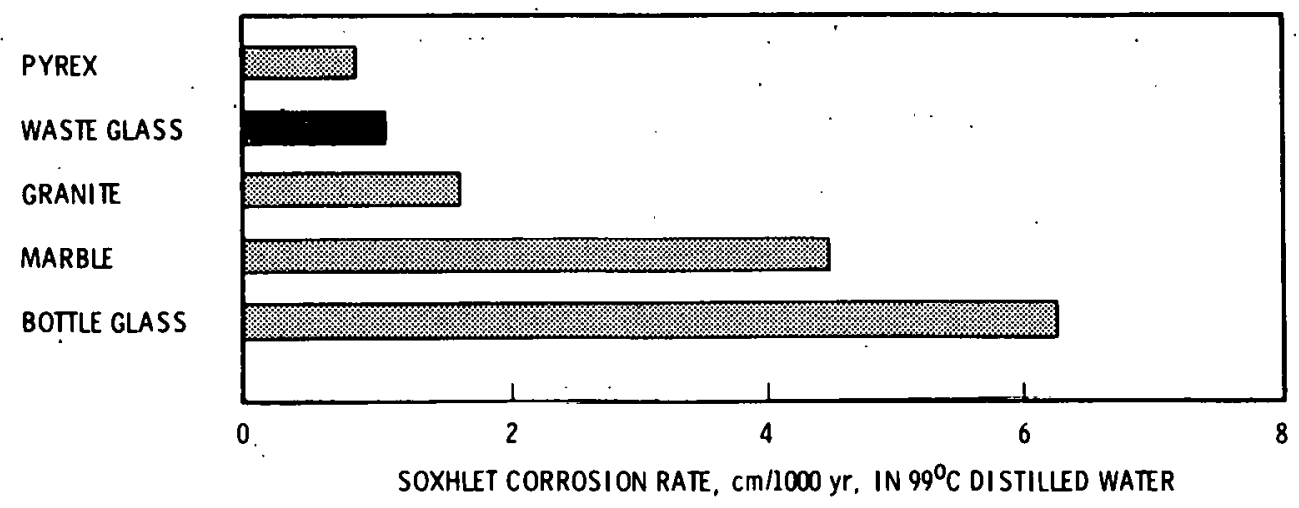

IIGURE 12. Cumpdrison of Corrosion Rates of Waste Glass and Other Durable Materials

GLASS ALTERATION DEPTH AFTER 1000 YEARS

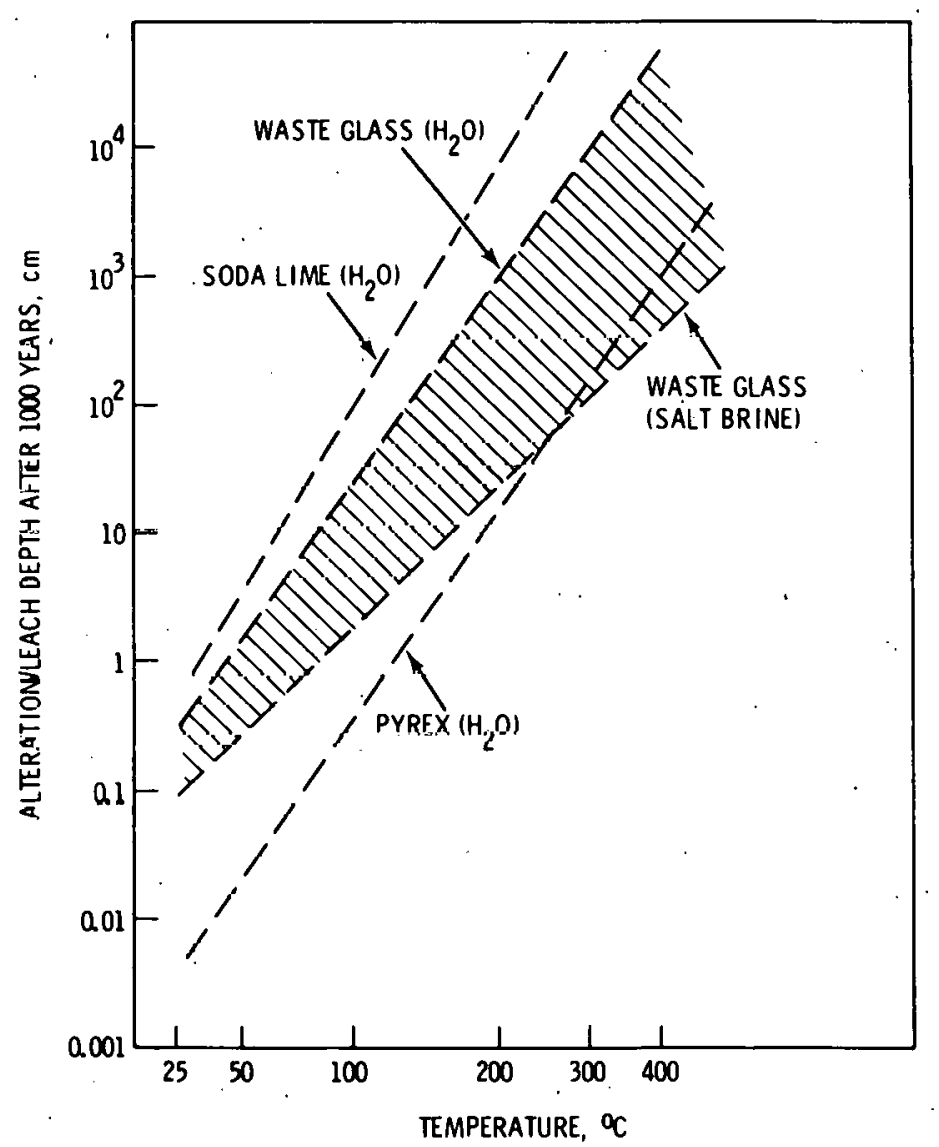

FIGURE 13. Temperature Effects on Glass Corrosion Rates 
TABLE 3. Energy Dissipated in Elastic Collisions by Various Nuclear Radiations, and Accumulations of Elastic-Collision-Energies in Radioactive Wastes

\begin{tabular}{|c|c|c|c|c|c|}
\hline \multirow{2}{*}{ Nuclear Particle } & \multirow[t]{2}{*}{$\begin{array}{c}\text { Energy Dissipated } \\
\text { in Elastic } \\
\text { Collisions, keV } \\
\end{array}$} & \multicolumn{2}{|c|}{$\begin{array}{c}\text { Cumulative Number } \\
\text { of Particles in } \\
\text { Wastes, (a) Aged } 12 \text { and } \\
80 \text { Years } \\
\left(1017 / \mathrm{cm}^{3}\right) \\
\end{array}$} & \multicolumn{2}{|c|}{$\begin{array}{c}\text { Cumulative Amount of } \\
\text { Collision Energy } \\
\text { Dissipation in Wastes, } \\
\text { Aged } 12 \text { and } 80 \text { Years } \\
\left(1019 \mathrm{keV} / \mathrm{cm}^{3}\right) \\
\end{array}$} \\
\hline & & $12 \mathrm{yr}$ & $80 \mathrm{yr}$ & $12 \mathrm{yr}$ & $80 \mathrm{yr}$ \\
\hline Recoil nucleus (100 keV) & 100 & 8.1 & 17.1 & 8.1 & 17.1 \\
\hline$\alpha(6 \mathrm{MeV})$ & $4-8$ & 8.1 & 17.1 & $0.3-0.6$ & $0.7-1.4$ \\
\hline $\begin{array}{l}B(>0.5 \mathrm{MeV} ; \\
\text { average }=1.5 \mathrm{MeV})\end{array}$ & $<0.1$ & 3 & 5 & $<0.3$ & $<0.5$ \\
\hline$\gamma(2 \mathrm{MeV})$ & $<<0.1$ & $<3$ & $<5$ & $<<0.3$ & $\ll 0.5$ \\
\hline Fission recoil & 5000 & $2 \times 10^{-5}$ & $4 \times 10^{-5}$ & 0.001 & 0.002 \\
\hline
\end{tabular}


Radiation damage effects, when extrapolated to long times, suggest energy storage of $\sim 50 \mathrm{cal} / \mathrm{g}$ and either positive or negative density changes occur (depending on the glass composition) in the $1 \%$ range. No radiation effectrelated changes of serious concern in terms of leachability or mechanical strength have been found for homogeneous glasses by ${ }^{244} \mathrm{Cm}$ doping experiments a simulating damage time of over $10^{5}$ years.

\section{HIGH-LEVEL WASTE}

In wet, as opposed to dry repositories, the encapsulation material for the waste glass--in addition to engineered barriers in the repository--can offer additional protection until the toxicity decreases to the level of natural materials. To be more specific, Figure 14 shows the volume of water in which a substance would have to be dispersed to render it harmless. Both spent fuel and high-level waste from 1 years' operation of a 1000 MWe PWR would reach a toxicity level equal to that of an equal volume of mercury or pitchblende ore in a few hundred years.

One such approach, under study by the Swedish KBS group, is shown in Figure 15.* The container holds 1 MTHM equivalent and has a total weight of 3.9 MT. The chromium-nickel steel container in which the vitrified waste is delivered from the reprocessing plant is not credited with any protective life of its own. Instead, the real protection is afforded by a canister made of lead and titanium, both possessing good resistance to corrosion. The lead also serves as a radiation shield reducing the radiation level and the radiolysis of the groundwater so that these contribute little to corrosion.

The corrosion resistance of the titanium casing derives entirely from the creation of a protective passivating layer. Under prevailing conditions, this passivating layer is self-healing when damaged. As long as this layer is intact, general corrosion of the material is extremely slow. Under the environmental conditions expected to prevail around the canisters in the final

\footnotetext{
*KBS-010, Handling of Spent Nuclear Fuel and Final Storage of Vitrified HighLevel Reprocessing Waste.
} 


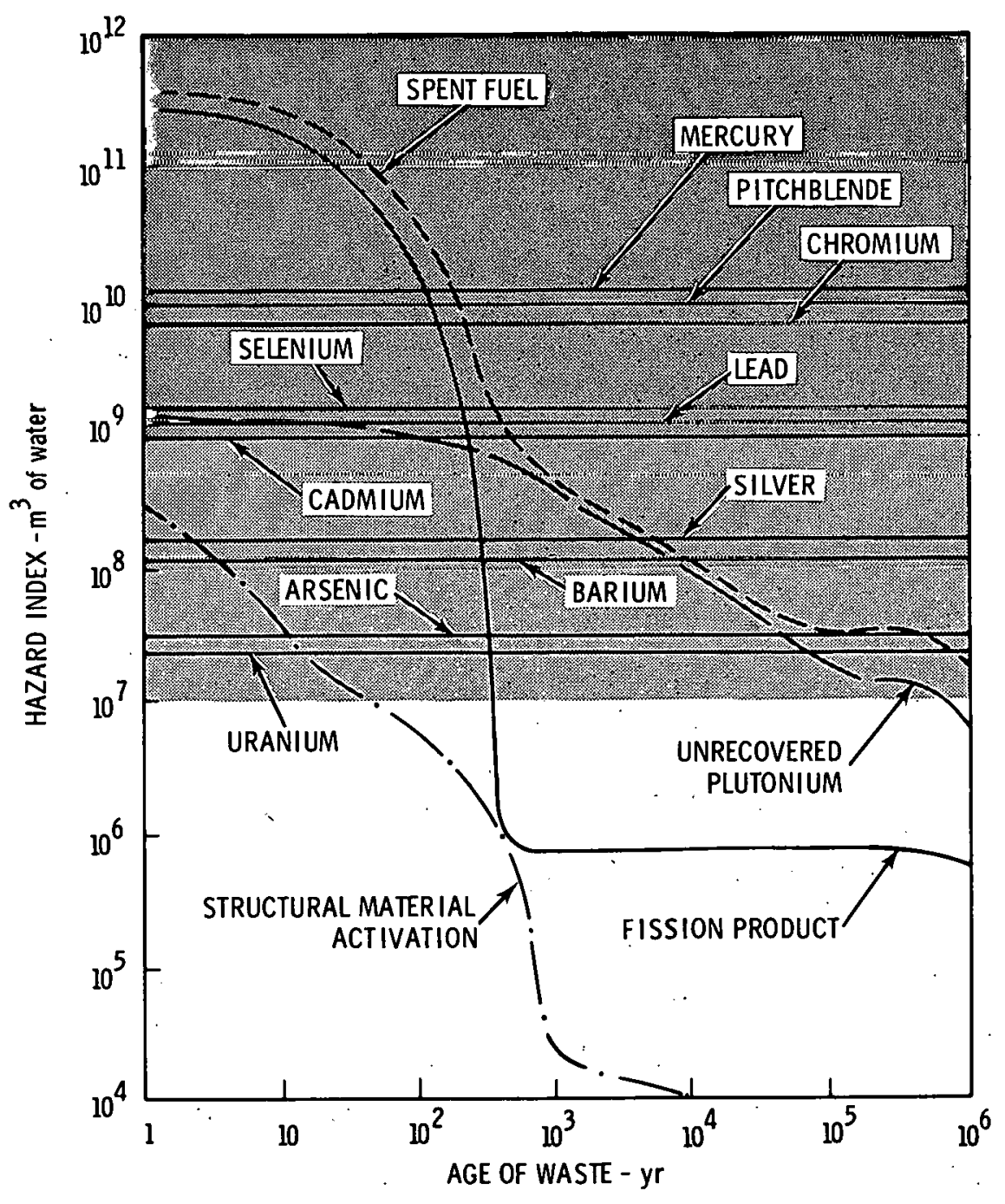

FIGURE 14. Toxicity Index of Spent Fuel and High-Level Waste*

*R. A. Heckman, Energy and Technology Review October 1977: Magnetic Fusion Research. 


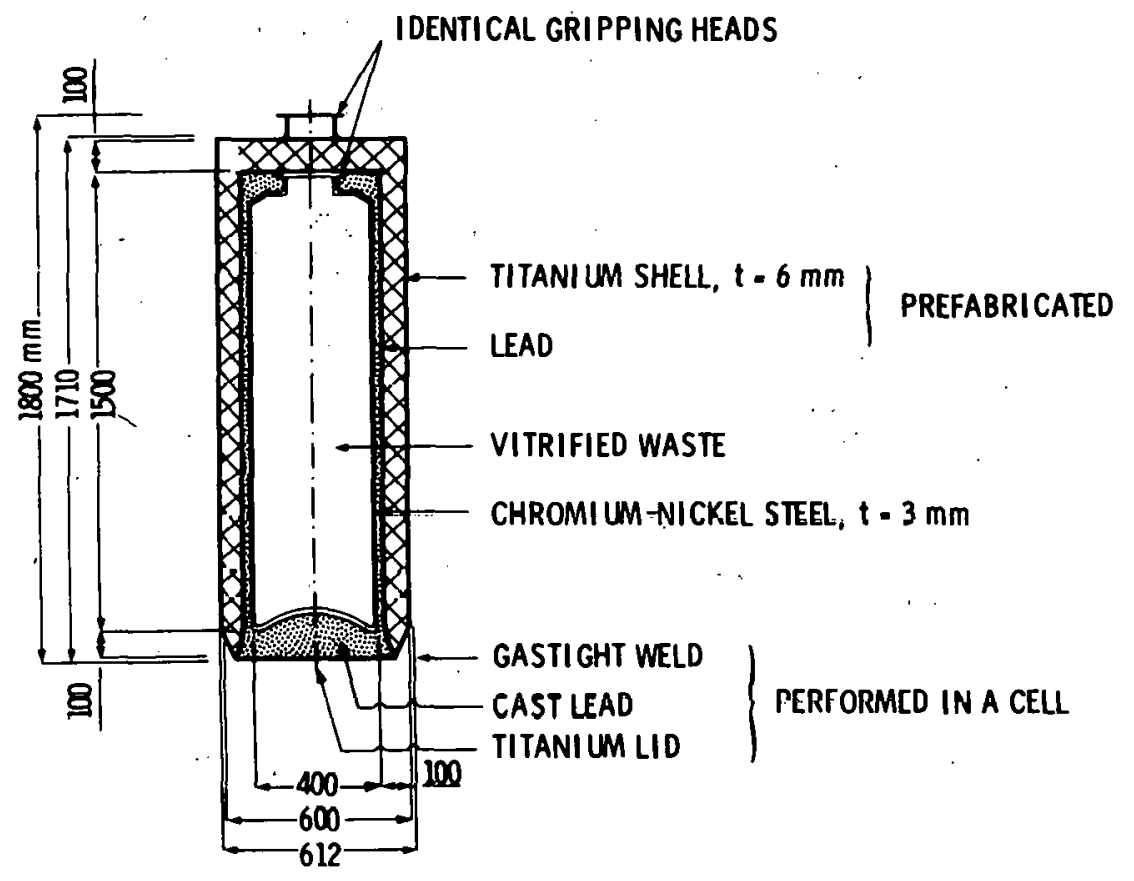

FIGURE 15. K'BS High-Level Waste Canister Concept

repository, local corrosion of titanium has not been observed at all. The titanium casing can be expected to remain intact for a very long time.

General corrosion of the lead' can be disregarded because it is protected by the titanium casing. If the titanium is penetrated, however, some pitting corrosion of the lead may be expected on the exposed surface. The quantity of lead which can then go into solution is estimated to be slightly more than $2 \mathrm{~kg}$ in 1000 years. The attack will penetrate down into the lead at a diminishing rate. It is tentatively estimated that pitting will penetrate the lead lining at the earliest about 500 years after the titanium casing has been penetrated, but this figure is probably grossly underestimated.

Since the U.S. repositories will be essentially dry, our primary approach is to investigate the protection by the waste form, a single metallic container and possibly an external engineered barrier. Figure 16 shows a typical canister and some of its characteristics. It should be noted that after 1000 years the canister is generating only $20 \mathrm{~W}$ and the gamma dose rate is only $1.6 \mathrm{R} / \mathrm{hr}$. 


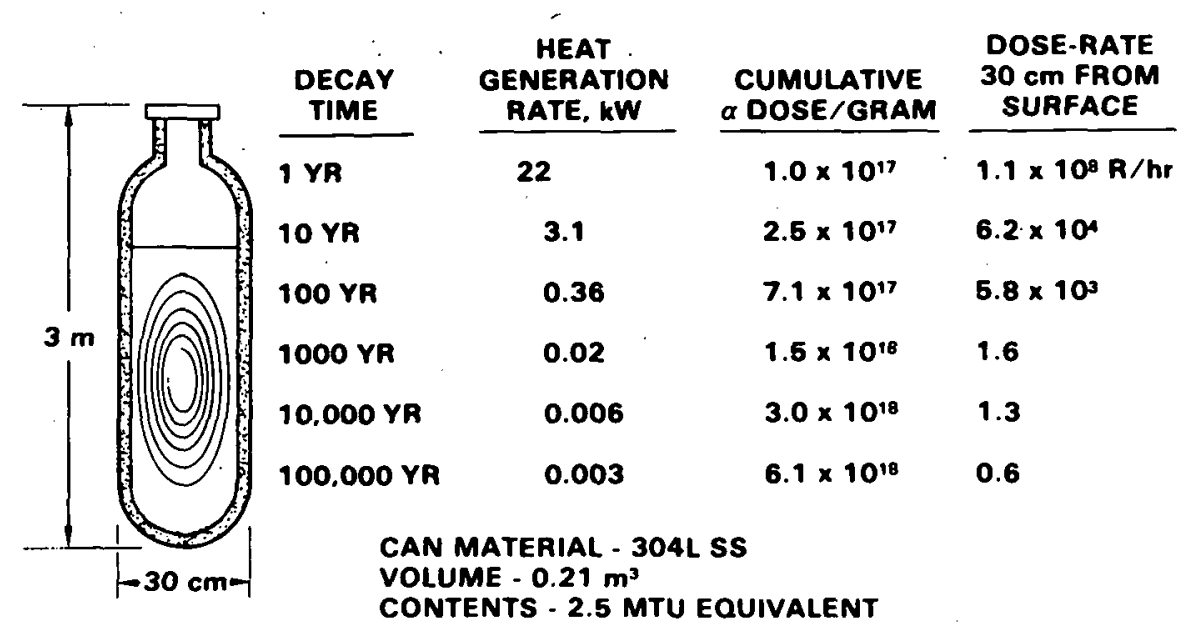

FIGURE 16. Typical High-Level Waste Canister

\section{REPOSITORIES}

Repository concepts, both in the U.S. and other nations, employ the highlevel waste form, its encapsulation, and the geosphere as a series of barriers to keep radionuclides from entering the ecosphere.

The design of a repository, both in terms of the heat generation rate of the packages, when emplaced and in terms of the general areal loading, will affect the temperature regime of the waste canisters.

One early design contemplated (Figure 17) for salt with high-density waste (10 yr cooled, $3.5 \mathrm{~kW}$ canister at emplacement) would have a canister wall temperature of $370^{\circ} \mathrm{C} 5$ years after burial. The presence of any water could cause severe corrosion problems, depending on how much the water and the moveillent of lie salt had increased thermal conductivities and reduced temperatures.

Increasing the cooling time before emplacement or decreasing the heat generation rate of the canisters (Figure 18) will markedly reduce temperatures, even below $100^{\circ} \mathrm{C}$ if desired.

One other temperature consideration in a repository is the long-term increase in temperature of the entire disposal horizon because of areal loading. Sandia Laboratories has analyzed the temperature rise in a salt 


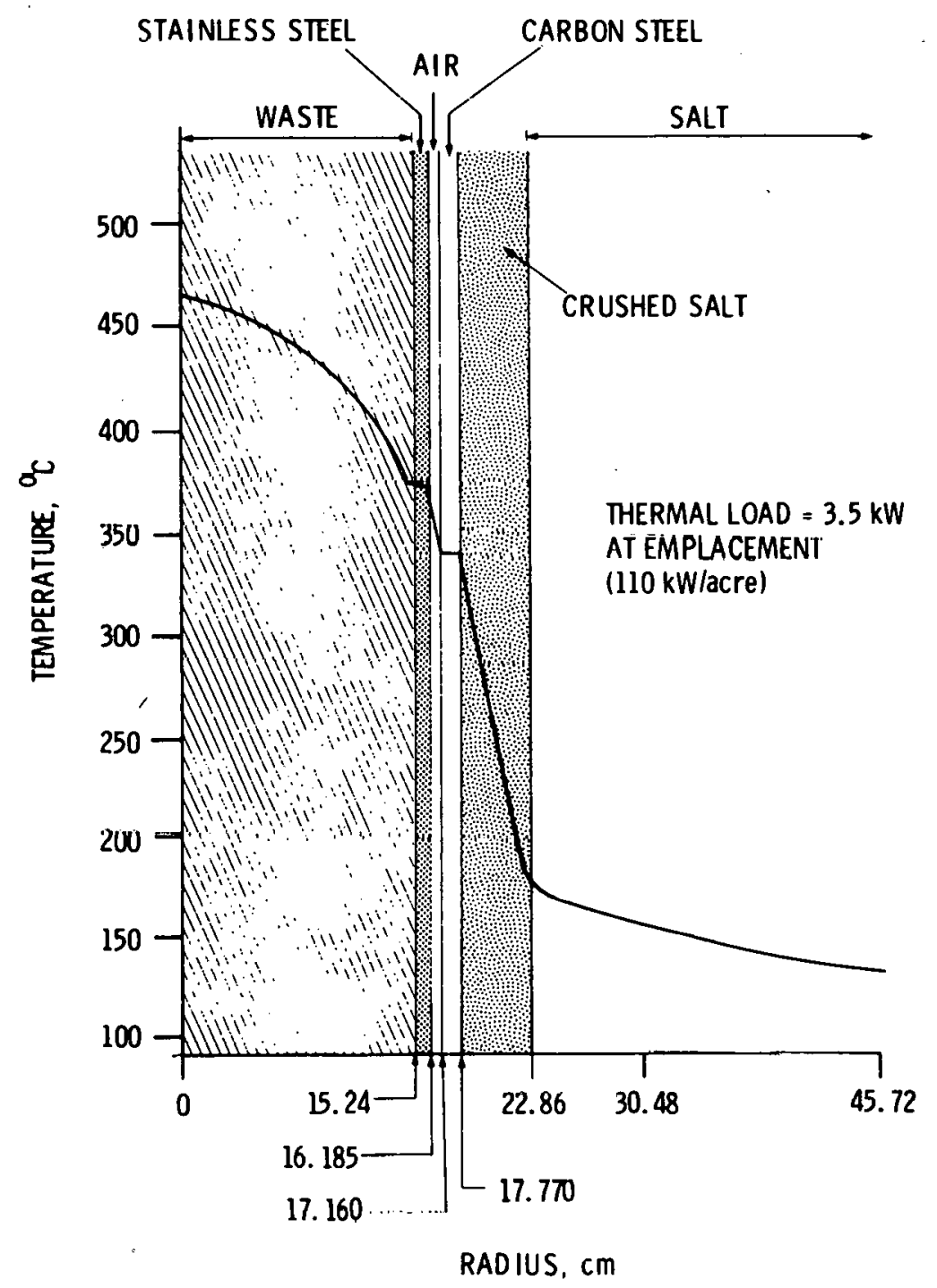

FIGURE 17. Temperature Versus Radius at Mid-Waste Level Time $=5$ Years

medium ( $50 \mathrm{~m}$ thick and $550 \mathrm{~m}$ from the surface) for various types of wastes, e.g., spent fuel, high-level waste from plutonium recycle, high-level waste from $\mathrm{UO}_{2}$ ruel, etc.

Although the data should not be directly compared, they do indicate that maximum temperatures are reached well after (e.g., 50 years) emplacement and closure of the repository. The average temperature rise (Figure 19) correlates well with areal loading. 


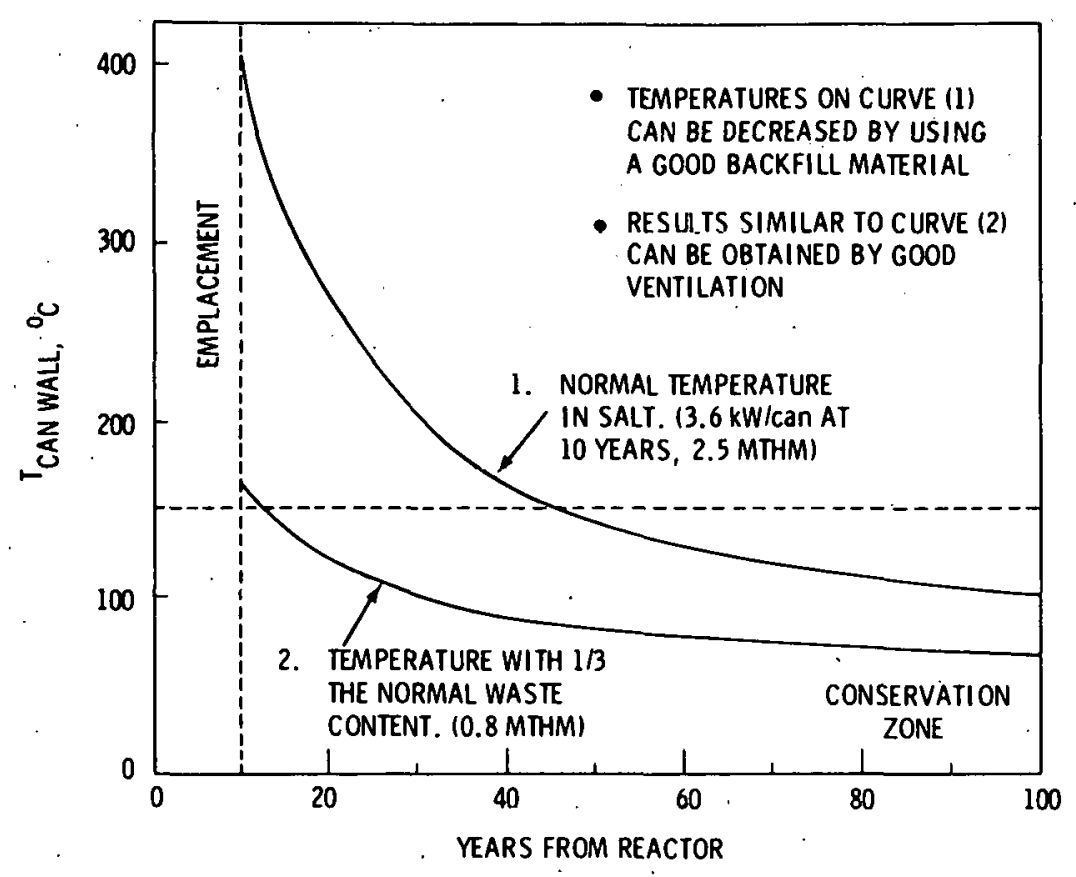

FIGURE 18. Reduction of Canister Wa11 Temperatures by (1) Aging or (2) Dilution of Waste

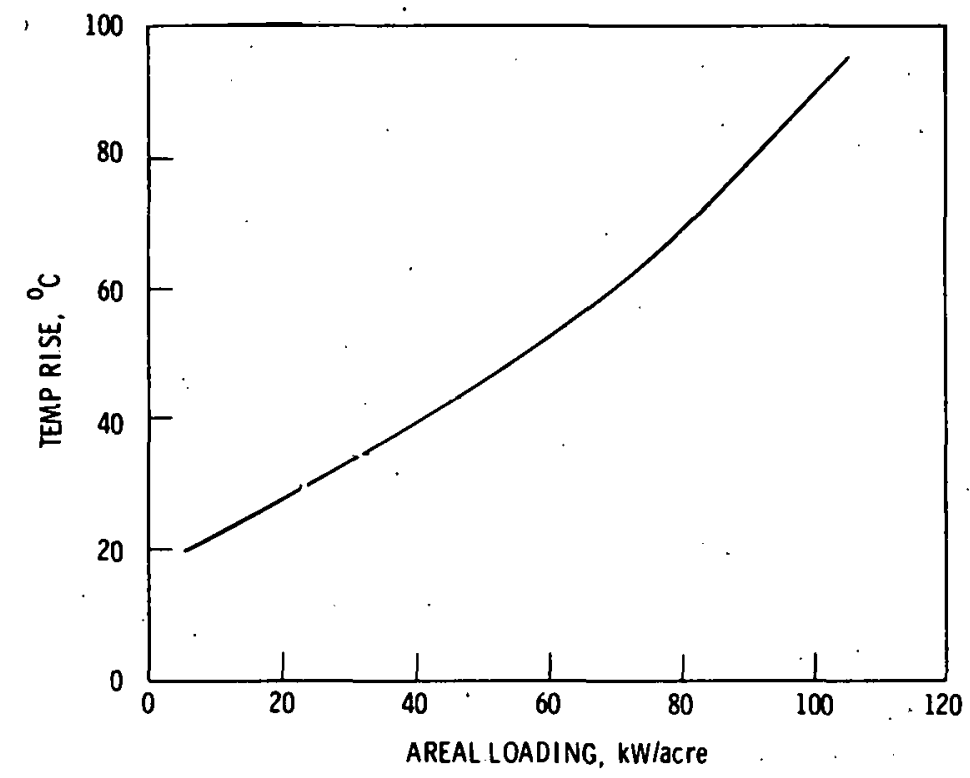

FIGURE 19. Avcrage Temperature Rise al Waste Disposal Level*

*Richard C. Lincoln, David W. Larson and Carl E. Sisson, Estimates of Relative Areas for the Disposal in Bedded Salt of LWR Wastes from Alternative Fuel Cycles, SAND-77-1816, Sandia Laboratories, A7buquerque, NM, Jalluary 1978. 
Based on previously presented arguments, a case can be made that it is important to protect the waste form by the can and other engineered barriers until the highly mobile but short-lived fission products decay, i.e., 200 to 500 years, rather than depending totally on the geosphere. This scenario will probably require a balance between the heat generation rate of the canister at time of emplacement, the decay rate of the canister, and the temperature rise in the repository caused by areal loading. Reasonable design values are available for all these variables.

With these limitations, it would seem readily feasible to provide an adequate engineering design 1 ife of hundreds of years. After all, there are many manmade structures over 3000 years old.

It is also noted that a counter case can be made that the rates of reaction, and perhaps equilibrium constants, of waste/rock reactions could be benefited by increased temperature to such an extent that the additional protection offered by the geosphere would more than compensate for reduction in waste form protection. Such a scenario would benefit by designs favoring high temperatures.

Data are being collected which will allow logical decisions, probably in between the extremes defined by these two scenarios.

\section{CONCLUSION}

The foregoing has been a quick overview of the status of management of high-level nuclear wastes both in the U.S. and certain other countries.

We personally feel that the predisposal technology required to condition high-level nuclear wastes is well developed and ready for commercial application subject to the additional development mentioned.

Although lhere still remain some technical chnices to be validated, we share the conclusion reached by many technical experts that with proper design parameters geologic media can be used for disposal of nuclear wastes without - significant risk. 